ISCKMC 2020

International Scientific Congress «KNOWLEDGE, MAN AND CIVILIZATION»

\title{
SPEECH STRATEGIES FOR RELIGIOUS IDEOLOGEMES INTERPRETATION AS CHARACTERISTIC OF MEDIA SPEECH PORTRAIT
}

\author{
Patimat Abdulaevna Lekova (a)*, Tamara Ibragimovna Magomedova (b) \\ *Corresponding author \\ (a) FSBEI Dagestan State University, 367025, Makhachkala, Gadzhiyev st., building 43-a, Russia, \\ liekova65@mail.ru \\ (b) FSBEI Dagestan State University, 367025, Makhachkala, Gadzhiyev st., building 43-a, Russia, \\ slovakia68@mail.ru
}

\begin{abstract}
The article attempts to substantiate the thesis that speech strategies for interpreting religious ideologemes contribute to the formation of ideas about the media speech portrait. The relevance of the study is determined by the lack of theoretical and methodological substantiation of the concept of "media speech portrait", the lack of theoretical and practical research allowing us to draw conclusions about media speech strategies of different typology. Religious ideologemes are considered as one of the ways of ideological marking of modern media texts. It is argued that in this capacity they contribute to the unification of two types of the discourse: religious and political and, consequently, the implementation of the most important speech strategy of the analyzed media, namely, calling the audience to take active action. Political and religious ideologemes enter into dialogue relations both in the journalistic texts of the analyzed media, and at the level of structuring publication materials through rubrication. The attitude towards the discursive construction of reality, characteristic of contemporary media, presupposes the activation of ideologemes in the system of speech strategies, excluding the distinction between the intention of opinion and fact. Religious ideologemes in journalistic texts of a certain genre organization (exhortation, guidance) are important semantic signals, a means of forming stereotypical and mythological constituents of the recipients' worldview.
\end{abstract}




\section{Introduction}

The media speech portrait is a phenomenon that is poorly studied in modern linguistics. There are only individual studies that touch on some aspects of the issue and do not offer general methods for constructing a speech portrait of a periodical (Kaminskaia, 2009; Sheigal, 2000).

\section{Problem Statement}

Meanwhile, the problem belongs to the category of urgent ones, since analysis of the media speech portrait included in various types of discourses (journalistic, political, media discourse, etc.) would allow drawing conclusions not only about the characteristics of the speech portrait of a particular publication, but also significantly expanding scientific ideas about the linguistic taste of the current era, about discursive practices relevant for modern mass communications. Comprehensive approaches to the system formation of ideas about the media speech portrait can be used as the basis for scientific observations over the linguistic behavior of various institutions, to form ideas about stable trends in the development of modern Russian language.

\section{Research Questions}

The research subject is the corpus of ideologemes of the religion axiocracy ( 279 units) recorded in the Dagestan Russian-language newspaper "Chernovik".

\section{Purpose of the Study}

The purpose of the study is to present an analysis of media speech strategies aimed at interpreting religious ideologemes, to reveal their functions in a journalistic text, and to discover facts of convergence of religious and socio-political discourses through an analysis of the ideologemes system in a particular publication.

\section{Research Methods}

In our opinion, one of the methodologically promising approaches to solving these issues is to appeal to the analysis of the concepts' system in the media. Revealing the frequency of concept positioning, their repetition, functions in the author's text and in the publication stylistics will make it possible to draw a number of productive conclusions about the characteristics of the publication speech portrait. The methodology of the study is based on a discursive approach, according to which linguistic reconstruction of the media speech portrait is possible taking into account the analysis of the worldview, stylistic, communicative-pragmatic and other characteristics of the publication. Besides, there is a possibility of taking into consideration the system of discursive relations of journalistic texts within the framework of a particular publication, the system of concepts and ideologemes that are formed under the influence of extralinguistic factors. The method of complex linguistic description, including the 
techniques of observation, generalization, interpretation and classification of speech strategies of individual authors and the media is used in the paper.

\section{Findings}

According to Foucault (1996), discourse is both a process and a result, and a way of forming a world picture ("vision"), which presupposes ordering the phenomena of reality in a variety of discursive practices (p. 30). The regulations of Foucault's theory have become productive for media linguistics, which also operates the concept of the reality discursive construction. In this context, the problem of violation of the media message objectivity and the problem of forming a world picture in the minds of recipients have been interpreted (Dijk, 1998; Dufek, 2017; Fairclough, 1997; Havlík, 2009).

The system of concepts in the media is built in accordance with the publication rubrics. Thus, the following permanent columns function in the Dagestan socio-political newspaper "Chernovik": "News", "Politics", "Economy", "Republic", "Religion", "Sport", "Middle class", "Society." Each of these rubrics implements its system of concepts. Therefore, concepts in the media context declare themselves in the system of ideologemes. The theoretical substantiation of the ideologemes genesis and their connection with concepts is represented in the papers of many researchers (Bakhtin, 1979; Chudinov, 2018; Dobrosklonskaia, 2014; Karaulov, 1987; Klushina, 2014; Malysheva, 2011).

Summarizing the results of observations in this area of linguistics, Piontek (2012) gives the following definition of the ideologeme: Ideologemes represent socially important ideas frozen in a certain verbal form and are their brief linguistic versification. They are distinguished by conceptual nature, manifested in the fact that they are addressed to the leading socio-political and moral-ethical concepts of this ethno-linguistic community. At the same time, ideologemes are not reducible to concepts, since they are linguistic units of a more abstract level than ideologemes and incorporate ideologemes as a generic notion named hyperonym (revolution as a hyperonym in relation to ideologemes - the Velvet Revolution, the October Revolution, the Orange Revolution, the Carnation Revolution) (Piontek, 2012, p. 8).

Being participants in political discourse, the media actively use various strategies to influence the audience. The speech portrait of modern media is characterized by the desire to implement dialogue relations with the audience, adjustment for discovering common positions, moods, for optimal implementation of the speech impact on the audience, attraction its attention, for introduction of manipulative strategies, etc. Russian media, participants in political discourse, are increasingly turning to the issue of interaction between politics and religion.

Politics and religion coexist in the contemporary media picture of the world. This fact finds its confirmation in the implementation of various communication strategies and certain speech practices.

Appealing to the analysis of religious ideologemes as a tool for the speech impact of opposition media on the audience, we refer to the classification of ideologemes that is relevant for our research, and which we will adhere to: "Ideologemes as value-motivated sign formations are grouped around one or another ideologically significant concept that serves as the basis for the formation of axiological categories (axiocategories). As a result, the ideologemes of the Russian language can be distributed over the following five categories: axiocategory of power, axiocategory of social structure, axiocategory of the 
enemy image, axiocategory of religion, axiocategory of cultural and philosophical values" (Zhuravlev, 2004, p. 5).

All of the above mentioned types of ideologemes coexist in the socio-political Russian-language Dagestan newspaper "Chernovik", which indicates the publication's desire to participate in both sociopolitical and religious-political discourse.

Herewith, the media speech portrait receives various characteristics. Being an active participant in political discourse, the media, through journalistic statements, participates in the processes of consolidating official ideologemes in the minds of mass audience ("vertical of power", "people", "authorities", etc.), as well as the creation, propagation, and consolidation of unofficial ideologemes in recipients' minds ("Mouthpiece of the Kremlin", "Hand of the Kremlin", "October Revolution", etc.). Besides, self-identifying as an opposition media, "Chernovik" participates in the processes of lowering official ideologemes, which often become the object of the author's irony, and sometimes sarcasm. Our observations have shown that political ideologemes are an integral part of manipulative media strategies.

Texts based on religious ideologemes have speech strategies characteristic of religious discourse. Ideologemes take part in clarifying, teaching, forming a certain type of personality behavior, comprehending religious truth. Interpretation of significant religious ideologemes is presented in journalistic texts: "Prophet", "Deputy of Allah", "Muslim", "Believer", etc. For instance, the journalistic interpretation of the "Kurban Bayram" ideologeme is as follows: "There are two images for the month of Ramadan. The first image ... Ramadan, causing problems, heavy, bringing hunger and thirst ... Longawaited Ramadan, revitalizing the nights, softening hearts. Ramadan, in which the treasures of the mercy of Allah Almighty descend to people" (Chernovik, 2019).

Religious ideologemes in the media space reflect a high degree of arabisms' actualization in the modern Russian-language media text associated with religious-worldview topics. The conducted statistical analysis indicates an average ratio of 5-9 arabisms per 150 words. The volume of covered words can be divided into several large thematic groups. Among them are Shariah terminology, proper names; geographical names of localities and attractions; words that describe a person's status from the point of view of Islam. An analysis of the recorded words of Arabic origin has showed that at least $25 \%$ of the vocabulary represented in journalistic texts refers to the so-called barbarisms. They perform the function of representing religious beliefs and worldview and behavioral aspects associated with them.

The author's speech strategy assumes both an explanation of religious dogma and the implementation of an attitude towards the formation of a recognizable style characteristic of the analyzed media. Religious ideologemes are included by the authors in the metaphors ("Ramadan, in which the treasures of the mercy of Allah Almighty descend to people"; "The train of life rushes with us and the best part of the road is the month of Ramadan"), in the system of comparisons ("Many of those who go all out for this world are zealous much more than we are - Muslims who strive for eternal life"; "The believer is like a palm tree. The older it is, the more generous its fertility becomes. Over the years, the palm tree becomes taller and more beautiful, more and more decorates the surrounding area, and its trunk only becomes stronger. Likewise a Muslim") and contrasts ("Muslims are often indignant that the state is trying to limit the activities of religion by the walls of mosques, but at the same time they do not notice that most often they limit themselves within this framework"; "Only the true Messenger of Allah 
(peace and blessings of Allah be upon him) succeeded, and people easily distinguished between the best and the worst, between the most unjust wicked and the most truthful prophet of the Almighty"), signaling a precedent situation ("Remember the five Pillars of Islam"; "Day of the Doom will come”; “...worship Allah shoulder to shoulder") (Chernovik, 2019).

The ideologeme is not only the semantic center of the article, the style-forming factor, but also an important structural and organizing component, since it is declared at all levels of the compositional organization of the text and is the entry point into the text.

Political and religious ideologemes enter into dialogue relations in the discourse of the analyzed media, and also participate in the formation of a balanced agenda and contribute to the creation of the effect of solving social issues and social conflicts. "Ramadan is the time when the principles of humanity are best manifested. People become as if equal. One does not starve when the other overeats. All members of the Muslim community, whether rich or needy, feel hunger and feed it together. A wealthy person experiences the problems of those in need, and each of them, finding himself in a situation where he desires a piece of bread or a glass of water, realizes the mercy of Allah Almighty that He gives people every day" (Chernovik, 2019). In this context, political and religious ideologemes are opposed and compared: society - Muslim society; equality - the principles of humanity; society members - Muslim society members.

Participation in religious discourse allows the media to declare the moral justification of their opposition: "Islam teaches a person to live in the real world. He does not oppose soul and body, spiritual and worldly, mind and faith. A Muslim is a freedom-loving person who rejects social passivity and humility in front of injustice"; "The Quran tells a person that he is the deputy of Allah on earth, who is called to creation, active life, and the establishment of justice. At the same time, a person should not forget that he will return to the Lord of all things, and that he will be accountable to Him"; "In general, people and society have fairly simple needs, such as security, food, stability. And if Muslims can actually show that they can give it to society, then they will receive support from them, which will become support for Islam itself" (Chernovik, 2019). The semantic opposition of political and religious ideologies is removed in these and many other examples. An equal sign is placed between such ideologemes as "Muslim" and "citizen" ("freedom-loving person"); "spiritual" and "worldly"; "Islam" - "stability", "prosperity." The author encourages his readers to comprehend and accept the religious norm of behavior, which does not contradict, but on the contrary, contributes to the formation of an active civic position, the fight against social injustice.

Religious ideologemes in the same context with axiocategories ideologemes of social structure and cultural and philosophical values characterize the speaker as a linguistic person with a tendency towards socio-philosophical understanding of reality: "Prophet Muhammad (peace and blessings of Allah be upon him) was the best man to raise the best generation that ever existed. He was followed by smart and courageous, sincere and intelligent, and after a certain time he was followed by the whole society around him. Then this society built a state and civilization. All who fought with the Messenger of Allah (peace and blessings of Allah be upon him) and feuded with his call, perished, despite the economic, political and military advantage they had" (Chernovik, 2019). 
Rhetorical questions and exclamations also belong to the category of effective speech strategies for influencing the audience. It should be noted that this speech strategy is equally in demand both in the political discourse of the publication and in the religious one, which contributes to their convergence, strengthening the role of ideologeme as a key word of a journalistic text. Here is an example of this text organization: "Let's take a look at ourselves. Are there not those among us, fasting, who deceive? Are there not those among us who break promises and act treacherously? After all, these are three signs of hypocrisy which the Messenger of Allah (peace and blessings of Allah be upon him) spoke about!" (Chernovik, 2019). Rhetorical questions are an appellative component of both political and religious discourse, which imply the implementation of an attitude to attract the audience's attention.

The speech portrait of the analyzed media is characterized, as it has already been formulated, by the adjustment for deciphering the hidden meanings of the sacred content and, at the same time, for combining discursive layers, namely, socio-political and religious. The ideologemes related to the axiological category of power are represented in the edition by 144 units: "Power", "Politician", "State", "Strong State"; "Democratic institutions", "Elections", "Power structures", "President", etc. The ideologemes of the axiological category of social structure are the most numerous - 350 units: "People", "Society", "Community", "New aristocracy", "Bourgeoisie", "Entrepreneur", "Population strata", "Equality", "Social conflict", etc. The ideologemes of the religion axiocracy are presented in the edition context by 279 units: “Allah”, "Prophet”, “Quran”, "Muslim”, “Believer”, "Mosque”, “Messenger of Allah", "Islam", etc.

\section{Conclusion}

Religious ideologemes and axiocracy ideologemes of the social structure are quantitatively similar and reflect the conceptually significant publication installation to clarify the social problem through an appeal to a religious text and tradition. Therefore, religious ideologemes are the key words of both religious and socio-political discourse.

Religious ideologemes are actively involved in the analyzed media in order to realize the installation on internal and external dialogics. We note that internal dialogics, consolidating with this provision, distinguishes not only journalistic texts with religious content (explanation, exhortation, etc.), but also texts with a socio-political dominant, containing an attitude to educate the audience, and a call to follow democratic society norms. External dialogics is a characteristic of intertextual relations referred to the process of "rolling" texts with each other.

The ideologemes of the religion axiocracy are included both in the processes of external and internal dialogics by the authors of journalistic texts. In particular, attention is drawn to the attraction of ideologemes to the process of decoding joint action forms. Deciphering the forms of joint action becomes more complicated in the process of building dialogical relations between the texts of different discourses because they are filled with new meanings. For instance, forms of joint action can be interpreted by referring to the axiocracy ideologemes of the social structure in texts with a religious semantic dominant. They provide the formation of stereotypical and mythologized ideas about the world, which are postulated in articles of a religious and educational nature. 
Besides, the active use of religious ideologemes facilitates the equalization of opinion and truth intention. It should be noted that the nondiscrimination of fact and opinion in current media discourse is the dominant speech strategy of contemporary media, claiming their right to form a certain picture of the world in the audience minds.

Religious ideologemes are actively involved in the world picture construction in texts addressed to a mass audience; they perform the function of standardizing speech utterance.

The appeal to religious ideologemes, the ways of their interpretation, inclusion in the processes of the structural and semantic organization of the media (rubrication) and journalistic texts testify to such qualities of the media speech portrait as attitude and dialogics. There is also the desire to correlate two types of discourse, namely, religious and political, the desire to reduce the degree of journalistic utterances aggressiveness, the implementation of the installation to call for joint action and contemplation.

The actualization of religious ideologemes in a secular publication signals such qualities of his speech portrait as the desire to unite the recipient and the addressee, as well as to encourage him to both religious and socio-political actions. The appeal to the ideologemes of the religion axiocracy as a media speech strategy provides the implementation of the attitude towards the formation of conscious choice illusion in recipients' minds. Religious ideologemes for the media are a way to put a distance from manipulative technologies and at the same time to use all the possibilities of this type of ideologemes as the most effective impact on the audience by instilling stereotypical and mythological ideas about reality. Religious ideologemes included in the speech strategies of the media serve as a guarantor of the most adequate deciphering of the text by the mass audience.

\section{References}

Bakhtin, M. M. (1979). Aesthetics of verbal creativity. Art.

Chernovik (2019). Socio-political newspaper. https://chernovik.net/

Chudinov, A. P. (2018). Political linguistics. LitRes.

Dijk, T. A. (1998). News as Discourse. Lawrence Erlbaum Associates.

Dobrosklonskaia, T. G. (2014). Medialinguistics: a systematic approach to learning the language of the media (modern English media speech). Flinta.

Dufek, O. (2017). Soňa Schneiderová: Analýza diskurzu a mediální text [Soňa Schneiderová: Discourse Analysis and Media Text]. Slovo a slovesnost, 78(4), 4.

Fairclough, N. (1997). Critical discourse analysis. A multidisciplinary introduction. Discourse as Social Interaction. In T. A. van Dijk (Ed.), Discourse Studies (pp. 271-280). Sage.

Foucault, M. (1996). The Will to Truth: beyond knowledge, power and sexuality. Works of different years. Kastal.

Havlík, M. (2009). Diskurzní praktiky křest’anských kazatelů při konstituování standardního relačního páru „my“- oni“" [Discourse practices of Christian preachers in constituting the standard relational pair "we" - "they"]. Slovo a slovesnost, 70(2), 10-16.

Kaminskaia, T. L. (2009). Addressee image in the texts of mass communication: a semantic and pragmatic study [Doctoral Dissertation]. SPb.

Karaulov, Iu. N. (1987). Russian language and linguistic personality. Science.

Klushina, N. I. (2014). Ideologemes theory. Political Linguistics, 4(50), 49-56.

Malysheva, E. G. (2011). Ideologeme as a linguo-cognitive phenomenon: definition and classification. Political Linguistics, 4(30), 32-41. 
Piontek, B. M. (2012). General linguistic factors of the ideologeme genesis as a category of political linguistics (based on the material of the Polish and Russian languages) [Doctoral Dissertation]. Moscow.

Sheigal, E. I. (2000). Semiotics of political discourse [Doctoral Dissertation]. Volgograd.

Zhuravlev, S. A. (2004). Ideologemes and their actualization in Russian lexicographic discourse [Doctoral Dissertation]. Kazan. 